\title{
散乱理論に基づく隣接地点間における地震動の空間変動特性の評価 EVALUATION OF CHARACTERISTICS OF SPATIAL VARIATION OF GROUND MOTION AT ADJACENT POINTS BASED ON SCATTERING THEORY
}

\author{
徳 光亮 ${ }^{* 1}$, 山本 優*2, 内山泰生 ${ }^{* 2}$, 大野 晋*3 \\ Ryoichi TOKUMITSU, Yu YAMAMOTO, Yasuo UCHIYAMA \\ and Susumu OHNO
}

\begin{abstract}
The relational equation of the inhomogeneity of the subsurface soil and the propagation distance of the ground motion with the spatial variation of the ground motion between adjacent points is constructed based on the scattering theory. By applying the relational equation to the response wave of the seismic simulation using the three-dimensional heterogeneous soil model and the observation records on the Chiba array, heterogeneous parameters of subsurface soil and the depth $L_{c}$ which affects the spatial variation of the seismic motion were estimated.
\end{abstract}

Keywords : Ground motion, Spatial variation, Scattering theory, 3-D heterogeneous soil model, Power spectrum, Chiba array 地震動, 空間変動, 散乱理論, 3 次元不均質地盤モデル, パワースペクトル, 千葉アレイ観測施設

\section{1.はじめに}

水平方向の離間距離が数 $\mathrm{m}$ 数十 $\mathrm{m}$ のごく隣接した地点間にお ける地震動の空間変動は、当該の敷地内に立地する建物への入力地 震動の低減効果またはねじれ、回転を励起させる効果があることが 指摘されている例えば 1)。隣接地点間で地震動の空間変動が発生する 大きな要因として、表層地盤における速度構造の不均質性が挙げら れる。耐震設計において地震動の空間変動の影響を適切に考慮し、 建物の地震応答評価の精度向上を図るためには、表層地盤の不均質 パラメータおよびモデル化すべき地盤深さを把握する必要がある。

表層地盤における速度構造の不均質パラメータのうち、鉛直方向 については、地盤調查により相関距離および变動係数を評価した事 例が存在する例えば 2)。水平方向の相関距離は鉛直方向に比べて長く なることが指摘されている例えば 3)。ただし水平方向の不均質性は、限 られた地盤調查結果に基づき導き出されたものと考えられる ${ }^{3)}$ こ から、評価の信頼性を向上させるためのさらなる調査または分析が 必要であると思われる。

地震動の空間変動を支配する地盤深さについては、筆者らが不均 質地盤モデルを用いた地震動シミュレーションおよびごく隣接する 地表観測点における地震観測記録の分析により推定した事例が存在 する ${ }^{4)}$, 5)。筆者らの検討では、観測点間の離間距離が大きくなると ともに地震動の空間変動に影響を与える地盤深さも深くなるが、離 間距離がある程度大きくなると、地震動の空間変動に影響を与える 地盤深さに頭打ちの傾向も見られた。ただし、こうした分析結果に 対する物理的な根拠については、これまで十分に解明することがで
きていない。

地震動の空間変動特性を理論的に評価した研究として、地殼を伝 播する波動場の特性を解明するために、光学分野における散乱理論 を導入した検討事例が存在する例えば 6)。Shapiro et al. (1993) 7)は水 平方向、鉛直方向で等方的な不均質地盤を対象に、地震動の散乱係 数と地盤の不均質パラメータとの関係を 1 次散乱理論に基づき定式 化している。Ritter et al. (1998)8)は Shapiro et al. (1993) 7)の結果 を応用し、地震動の空間変動を地盤の速度構造の相関距離、変動係 数および伝播距離の関数で表現している。

本検討では Shapiro et al. (1993) 7) 等を参考に、水平方向と鉛直 方向で非等方的な不均質地盤を想定し、 $\mathrm{S}$ 波速度の相関距離、变動 係数等を不均質パラメータとして、隣接地点間における地震動の空 間変動の評価式を構築する。また 3 次元不均質地盤モデルを用いた 地震動シミュレーションにより地表の地震応答波形を計算し、隣接 地点間より抽出した波形に本評価式を適用することにより、地震動 の空間変動に影響を与える地盤深さについて考察する。さらに、地 表のごく隣接する地点間で得られた地震観測記録に本評価式を適用 することにより、表層地盤における $\mathrm{S}$ 波速度の相関距離および変動 係数の推定を試みる。

\section{2. 隣接地点間における地震動の空間変動の評価式の構築}

地盤の不均質パラメータと隣接地点間における地震動の空間変動 との関係を Shapiro et al.(1993) 7)および Ritter et al. (1998)8)を参 考に整理し、地震動の空間変動を支配する地盤深さを不均質地盤の
*1 大成建設(侏技術センター 工修

*2 大成建設(侏技術センター 博士 (工学)

*3 東北大学災害科学国際研究所 准教授. 博士 (工学)
Taisei Advanced Center of Technology, Taisei Corporation, M.Eng.

Taisei Advanced Center of Technology, Taisei Corporation, Dr.Eng.

Assoc. Prof., International Research Institute of Disaster Science, Tohoku Univ., Dr.Eng. 
相関距離および変動係数との関係式で表現する。

\section{1. 地震観測記録のばらつき度合いと散乱係数との関係}

Ritter et al. (1998)8)に基づき、地震観測記録のコヒーレントな成 分およびばらつき成分と、散乱係数との関係を定義する。

任意の点 $r$ における時刻歴波形 $u_{t}(r, t)$ をコヒーレントな成分（ $r$ 以 外の観測点との時刻歴波形の平均） $\langle u(r, t)\rangle$ およびばらつき成分 $u_{f}(r, t)$ に分離し、(1) 式のように表現する。

$$
u_{t}(r, t)=\langle u(r, t)\rangle+u_{f}(r, t)
$$

また、地震動のばらつき度合いの指標ととして、(2) 式を定義する。

$$
\varepsilon=\frac{\left|u_{f}(r, t)\right|}{|\langle u(r, t)\rangle|}
$$

地盤の非線形性に伴うエネルギー損失を無視できると仮定すると、 波形のコヒーレントな成分は散乱のみによってエネルギーが低減す る。したがって、波形全体のエネルギーI $I_{t}$ は、コヒーレントな波形の エネルギー $I_{c}$ および散乱に伴う波形のエネルギーI $I_{f}$ 用いて、(3) 式 のとおり表現できる。

$$
I_{t}=I_{c}+I_{f}
$$

$I_{c}=|\langle u\rangle|^{2} 、 I_{f}=\left|u_{f}\right|^{2}$ であるから、 $\left\langle\varepsilon^{2}\right\rangle$ は

（2）式を用いて

(4) 式 のとおり表現できる。

$$
\left\langle\varepsilon^{2}\right\rangle=\frac{\left|u_{f}\right|^{2}}{|\langle u\rangle|^{2}}=\frac{I_{t}}{I_{c}}-1
$$

対象とする地盤内における波動場のエネルギーが一定の場合（内 部減衰がない場合)、(4) 式の $I_{t} / I_{c}$ は（5）式のように距離の指数関 数で表現できる。

$$
I_{t} / I_{c} \approx e^{2 \alpha L}
$$

ここで、 $\alpha$ : 散乱係数、 $L$ : 不均質地盤を波動が伝播する距離（鉛 直方向に伝播する場合、地盤深さ)

\section{2. 散乱係数の計算 \\ (1) 散乱断面積 $\sigma$}

Shapiro et al.(1993) 7)は単位体積中の不均質媒質における散乱断 面積 $\sigma$ を用いて散乱係数 $\alpha$ を定式化しているが、 $\sigma$ の導出過程は文献 の中で解説されていない。本検討では $\alpha$ の定式化にあたり、Born et al.(2006)9)および Ishimaru(1978)10)を参考に $\sigma$ の求め方を整理する。

Fig. 1 に示すように、単位ベクトル $\boldsymbol{s}$ の方向で不均質媒質 $V$ に入射 した波動場が、不均質媒質内の基準点 $\mathrm{O}$ からべクトルrに位置する 観測点 $\mathrm{P}$ に到達する成分を $U(\boldsymbol{r})$ とし、さらに $U(\boldsymbol{r})$ に含まれる散乱場 の成分を $U^{S}(\boldsymbol{r})$ とすると、 $U^{S}(\boldsymbol{r})$ は（6）式のとおり表現される ${ }^{9)}$ 。

$$
U^{s}(\boldsymbol{r})=\int_{V} F\left(\boldsymbol{r}^{\prime}\right) U\left(\boldsymbol{r}^{\prime}\right) \frac{e^{i k\left|r-r^{\prime}\right|}}{\left|\boldsymbol{r}-\boldsymbol{r}^{\prime}\right|} d V^{\prime}
$$

ここで、 $\boldsymbol{r}^{\prime}$ : 不均質媒質内の基準点から不均質媒質内の点 $\mathrm{Q}$ まで の位置ベクトル、 $i$ : 虚数単位、 $k$ : 波数

（6）式中の $F\left(\boldsymbol{r}^{\prime}\right)$ は不均質媒質における散乱ポテンシャルで、 式のように表現される ${ }^{9)}$

$$
F\left(\boldsymbol{r}^{\prime}\right)=\frac{k^{2}}{4 \pi}\left[\left\{1+n_{1}\left(\boldsymbol{r}^{\prime}\right)\right\}^{2}-1\right]
$$

ここで、 $n_{1}\left(\boldsymbol{r}^{\prime}\right)$ : 伝播速度の変動分

$n_{1}\left(\boldsymbol{r}^{\prime}\right)$ 《1の場合、(7) 式における $n_{1}\left(\boldsymbol{r}^{\prime}\right)$ の 2 乗の項を無視し、(8) 式のとおり近似できる。

$$
F\left(\boldsymbol{r}^{\prime}\right) \approx \frac{k^{2}}{4 \pi}\left\{2 n_{1}\left(\boldsymbol{r}^{\prime}\right)\right\}=\frac{k^{2}}{2 \pi}\left\{n_{1}\left(\boldsymbol{r}^{\prime}\right)\right\}
$$

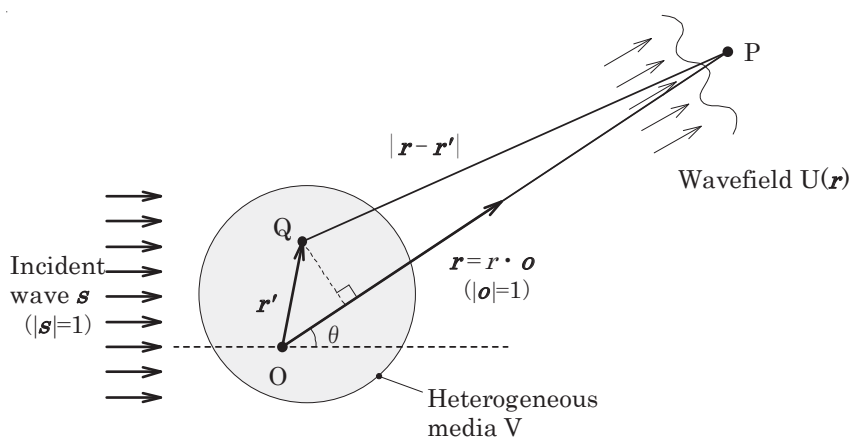

Fig. 1 Schematic illustration of the Plane Wave Propagating in a Scattering Volume and the Scattering Wave

$\boldsymbol{r}$ の大きさが累の大きさに比べて十分に大きい場合、（6）式中の $\left|\boldsymbol{r}-\boldsymbol{r}^{\prime}\right|$ は、(9) 式のとおり近似できる 9)。

$$
\left|\boldsymbol{r}-\boldsymbol{r}^{\prime}\right| \approx r-\boldsymbol{o} \cdot \boldsymbol{r}^{\prime}
$$

ここで、o : 不均質媒質内の基準点 $\mathrm{O}$ から観測点 $\mathrm{P}$ までの単位心゙ クトル
(9) 式を
（6）式中の $e^{i k\left|r-r^{\prime}\right|}$ に代入すると、
（10）式が得られる。

$$
\frac{e^{i k\left|r-r^{\prime}\right|}}{\left|\boldsymbol{r}-\boldsymbol{r}^{\prime}\right|} \approx \frac{e^{i k r}}{r} e^{-i k o \cdot r}
$$

（10）式を（6）式に代入すると、観測点 $\mathrm{P}$ において観測される散 乱場 $U^{S}(\boldsymbol{r})$ は（11）式のように表現できる。

$$
U^{s}(\boldsymbol{r})=\int_{V} F\left(\boldsymbol{r}^{\prime}\right) U\left(\boldsymbol{r}^{\prime}\right) \frac{e^{i k r}}{r} e^{-i k \boldsymbol{o} \cdot \boldsymbol{r}^{\prime}} d V^{\prime}=f(\boldsymbol{o}, \boldsymbol{s}) \frac{e^{i k r}}{r}
$$

ここで (11) 式の右辺の $f(\boldsymbol{o}, \boldsymbol{s})$ は、不均質媒質に $\boldsymbol{s}$ の向きに入射し た平面波に対するoの向きの散乱波の振幅を意味する。

（11）式の $F\left(\boldsymbol{r}^{\prime}\right)$ に（8）式を代入すると、(11) 式の $f(\boldsymbol{o}, \boldsymbol{s})$ は 式のように表現できる。

$$
\begin{aligned}
f(\boldsymbol{o}, \boldsymbol{s}) & =\int_{V} F\left(\boldsymbol{r}^{\prime}\right) U\left(\boldsymbol{r}^{\prime}\right) e^{-i k \boldsymbol{o} \cdot \boldsymbol{r}^{\prime}} d V^{\prime} \\
& =\int_{V} \frac{k^{2}}{2 \pi} n_{1}\left(\boldsymbol{r}^{\prime}\right) U\left(\boldsymbol{r}^{\prime}\right) e^{-i k \boldsymbol{o} \cdot \boldsymbol{r}^{\prime}} d V^{\prime}
\end{aligned}
$$

(12）式の $U\left(\boldsymbol{r}^{\prime}\right)$ は、不均質媒質 $V$ の伝播速度の変動が小さく、散乱 が弱い場合、Born 近似を適用し、（13）式のとおり表現できる 9)。

$$
U\left(\boldsymbol{r}^{\prime}\right) \approx e^{i k s \cdot r^{\prime}}
$$

（13）式を（12）式に代入すると（14）式が得られる。

$$
\begin{aligned}
f(\boldsymbol{o}, \boldsymbol{s}) & =\int_{V} \frac{k^{2}}{2 \pi} n_{1}\left(\boldsymbol{r}^{\prime}\right) e^{i k s \cdot \boldsymbol{r}^{\prime}} e^{-i k \boldsymbol{o} \cdot \boldsymbol{r}^{\prime}} d V^{\prime} \\
& =\frac{k^{2}}{2 \pi} \int_{V} n_{1}\left(\boldsymbol{r}^{\prime}\right) e^{i k(\boldsymbol{s}-\boldsymbol{o}) \cdot \boldsymbol{r}^{\prime}} d V^{\prime} \\
& =\frac{k^{2}}{2 \pi} \int_{V} n_{1}\left(\boldsymbol{r}^{\prime}\right) e^{i \boldsymbol{k}_{\boldsymbol{s}} \cdot \boldsymbol{r}^{\prime}} d V^{\prime}
\end{aligned}
$$

（14）式において、 $\boldsymbol{k}_{s}=k(\boldsymbol{s}-\boldsymbol{o})$ とした。またベクトル $\boldsymbol{k}_{s}$ の大きさ $k_{s}$ は、Fig. 1 に示すように、単位ベクトル $\boldsymbol{s}$ と的のなす角を $\theta$ とすると、 (15）式となる 10)。

$$
k_{s}=2 k \sin \frac{\theta}{2}
$$

ここで、不均質媒質 $V$ の単位体積より微小立体角に散乱される波 動場の強さを $d \sigma(\boldsymbol{o}, \boldsymbol{s})$ とすると、 $d \sigma(\boldsymbol{o}, \boldsymbol{s})$ と散乱振幅 $f(\boldsymbol{o}, \boldsymbol{s})$ との間に (16) 式の関係がある 10)。 


$$
d \sigma(\boldsymbol{o}, \boldsymbol{s})=\frac{1}{V}\left\langle f(\boldsymbol{o}, \boldsymbol{s}) f^{*}(\boldsymbol{o}, \boldsymbol{s})\right\rangle
$$

ここで、 $f^{*}(\boldsymbol{o}, \boldsymbol{s})$ は $f(\boldsymbol{o}, \boldsymbol{s})$ の共役複素数を示す。また、右辺の〈〉は 平均を示す。

（16）式の $f(\boldsymbol{o}, \boldsymbol{s})$ に（14）式を代入すると、（17）式となる。 $d \sigma(\boldsymbol{o}, \boldsymbol{s})$

$$
=\frac{k^{4}}{4 \pi^{2} V} \int_{V} \int_{V}\left\langle n_{1}\left(\boldsymbol{r}_{1}{ }^{\prime}\right) \cdot n_{2}\left(\boldsymbol{r}_{2}{ }^{\prime}\right)\right\rangle e^{i k_{s} \cdot\left(\boldsymbol{r}_{1}{ }^{\prime}-\boldsymbol{r}_{2}{ }^{\prime}\right)} d V_{1}{ }^{\prime} d V_{2}{ }^{\prime}
$$

また、不均質媒質内における基準点 $\mathrm{O}$ から位置ベクトル $\boldsymbol{r}_{1}{ }^{\prime}$ の地 点および $\boldsymbol{r}_{2}{ }^{\prime}$ の地点における伝播速度の変動分の相関関数を $B_{n}\left(\boldsymbol{r}_{d}\right)$ とすると、 $B_{n}\left(\boldsymbol{r}_{d}\right)$ は（18）式となる 10$)$

$$
\begin{gathered}
B_{n}\left(\boldsymbol{r}_{d}\right)=\left\langle n_{1}\left(\boldsymbol{r}_{1}{ }^{\prime}\right) \cdot n_{2}\left(\boldsymbol{r}_{2}{ }^{\prime}\right)\right\rangle \\
\text { ここで、} \boldsymbol{r}_{d}=\boldsymbol{r}_{1}{ }^{\prime}-\boldsymbol{r}_{2}{ }^{\prime} \\
\left(\boldsymbol{r}_{1}{ }^{\prime}+\boldsymbol{r}_{2}{ }^{\prime}\right) / 2=\boldsymbol{r}_{c} \text { とし、(18) 式を (17) 式に代入すると、 } d \sigma(\boldsymbol{o}, \boldsymbol{s})
\end{gathered}
$$

は（19）式のように表現できる10)。

$$
d \sigma(\boldsymbol{o}, \boldsymbol{s})=\frac{k^{4}}{4 \pi^{2} V} \int_{V} d V_{c} \int_{-\infty}^{\infty} B_{n}\left(\boldsymbol{r}_{d}\right) e^{i \boldsymbol{k}_{s} \cdot \boldsymbol{r}_{d}} d V_{d}
$$

(19) 式において、 $V_{c}$ および $V_{d}$ はベクトル $\boldsymbol{r}_{c}$ および $\boldsymbol{r}_{d}$ がとりうる空 間を示す。またベクトル $\boldsymbol{r}_{d}$ の大きさが伝播速度の変動の相関距離よ りも大きい範囲では、 $B_{n}\left(\boldsymbol{r}_{d}\right)$ の值はほぼ無視できることから、 $V_{d}$ の 積分の範囲をーの〜它している ${ }^{10)}$ 。

不均質媒質における伝播速度の変動のスペクトル密度を $\Phi_{n}\left(\boldsymbol{k}_{s}\right)$ とすると、 $\Phi_{n}\left(\boldsymbol{k}_{s}\right)$ は $B_{n}\left(\boldsymbol{r}_{d}\right)$ のフーリエ変換で表現できることから、 (20) 式となる 10)。

$$
\Phi_{n}\left(\boldsymbol{k}_{s}\right)=\frac{1}{(2 \pi)^{3}} \int_{-\infty}^{\infty} B_{n}\left(\boldsymbol{r}_{d}\right) e^{i \boldsymbol{k}_{s} \cdot \boldsymbol{r}_{d}} d V_{d}
$$

（20）式を（19）式に代入すると、 $d \sigma(\boldsymbol{o}, \boldsymbol{s})$ は（21）式のとおり表 現できる。

$$
d \sigma(\boldsymbol{o}, \boldsymbol{s})=2 \pi k^{4} \Phi_{n}\left(\boldsymbol{k}_{s}\right)
$$

単位体積中の不均質媒質における散乱断面積 $\sigma(\boldsymbol{o}, \boldsymbol{s})$ は（22）式の とおり、 $d \sigma(\boldsymbol{o}, \boldsymbol{s})$ を全立体角で積分することにより得られる 10$) 。$

$$
\sigma(\boldsymbol{o}, \boldsymbol{s})=\int d \sigma(\boldsymbol{o}, \boldsymbol{s}) d \Omega
$$

（22）式に（21）式を代入し、 $d \Omega$ を極座標に変換すると、（23）式 のように表現できる。

$$
\sigma(\boldsymbol{o}, \boldsymbol{s})=2 \pi k^{4} \int_{0}^{2 \pi} d \phi \int_{0}^{\pi} \sin \theta \Phi_{n}\left(\boldsymbol{k}_{s}\right) d \theta
$$

ここで、 $\phi$ : 平面波の入射方向（s）に対する偏角

\section{（2）散乱角 $\psi$ おび $\Phi_{n}\left(\boldsymbol{k}_{s}\right)$ の設定}

本検討では後述するとおり、河原 ${ }^{12)}$ による既往の研究を整理した 結果を踏まえ、不均質媒質を伝播する地震波は特定の散乱角 $\psi$ の範 囲内で散乱すると考える。このとき、全立体角に対する $\psi$ の範囲内 の割合 $\gamma$ は、(24) 式のとおりとなる。

$$
\gamma=\frac{1-\cos \psi}{2}
$$

$\sigma(\boldsymbol{o}, \boldsymbol{s})$ および（24）式の $\gamma$ を用いて、散乱係数 $\alpha(\boldsymbol{o}, \boldsymbol{s})$ は（25）式の とおり表現できる。

$$
\alpha(\boldsymbol{o}, \boldsymbol{s})=\gamma \sigma(\boldsymbol{o}, \boldsymbol{s})=2 \pi \gamma k^{4} \int_{0}^{2 \pi} d \phi \int_{0}^{\pi} \sin \theta \Phi_{n}\left(\boldsymbol{k}_{s}\right) d \theta
$$

$\sin \theta d \theta=k_{s} d k_{s} / k^{2}$ であることを考慮すると ${ }^{10)} 、$

（25）式は
式のとおり表現できる。

$$
\alpha(\boldsymbol{o}, \boldsymbol{s})=\gamma \sigma(\boldsymbol{o}, \boldsymbol{s})=4 \gamma \pi^{2} k^{2} \int_{0}^{2 k} \Phi_{n}\left(\boldsymbol{k}_{s}\right) k_{s} d k_{s}
$$

Shapiro et al.(1993) 7)は $\gamma$ に相当する值を 0.5 としており、（26） 式の $\gamma$ に 0.5 を代入すると、Shapiro et al.(1993) 7)および Ritter et al.(1998) 8)で示されている散乱係数の評価式が得られる。

(26) 式の $\Phi_{n}\left(\boldsymbol{k}_{s}\right)$ として、Ritter et al. (1998) 8) では不均質性を水 平方向、鉛直方向で等方的と仮定し、ガウス型および指数型の $\Phi_{n}\left(\boldsymbol{k}_{s}\right)$ を（27）式および（28）式で表現している。

$$
\begin{gathered}
\Phi_{n}\left(\boldsymbol{k}_{s}\right)=\frac{\mu^{2} a^{3}}{8 \pi \sqrt{\pi}} \exp \left(-\frac{k_{s}{ }^{2} a^{2}}{4}\right) \\
\Phi_{n}\left(\boldsymbol{k}_{s}\right)=\frac{\mu^{2} a^{3}}{\pi^{2}\left(1+k_{s}{ }^{2} a^{2}\right)^{2}}
\end{gathered}
$$

ここで、 $a$ : 不均質媒質における相関距離

$$
\mu \text { : 変動係数 }\left(=\sqrt{\left\langle n_{1}{ }^{2}\right\rangle}\right)
$$

これに対し、本検討では $\Phi_{n}\left(\boldsymbol{k}_{s}\right)$ を非等方的なガウス型および指数 型で表現する。ガウス型の $\Phi_{n}\left(\boldsymbol{k}_{s}\right)$ を（29）式で表現する 10)。

$$
\begin{aligned}
& \Phi_{n}\left(\boldsymbol{k}_{s}\right)= \frac{\mu^{2} a_{1} a_{2} a_{3}}{8 \pi \sqrt{\pi}} \exp \left(-\frac{k_{s 1}{ }^{2} a_{1}{ }^{2}+k_{s 2}{ }^{2} a_{2}{ }^{2}+k_{s 3}{ }^{2} a_{3}{ }^{2}}{4}\right) \quad(29) \\
& \text { ここで、 } a_{1} \text { : 不均質媒質における } x \text { 軸方向の相関距離 } \\
& a_{2} \text { : 不均質媒質における } y \text { 軸方向の相関距離 } \\
& a_{3} \text { : 不均質媒質における } z \text { 軸方向の相関距離 } \\
& k_{s 1}=k_{s} \sin \theta \cos \phi: \text { 不均質性を定義する } x \text { 軸方向の波数 } \\
& k_{s 2}=k_{s} \sin \theta \sin \phi: \text { 不均質性を定義する } y \text { 軸方向の波数 } \\
& k_{s 3}=k_{s}(1-\cos \theta): \text { 不均質性を定義する軸方向の波数 }
\end{aligned}
$$

本検討では、水平 2 方向の不均質性は等方的 $\left(a_{1}=a_{2}\right)$ とする。 （29）式を（25）式に代人すると、 $\alpha(\boldsymbol{o}, \boldsymbol{s})$ は（30）式となる。

$$
\begin{aligned}
\alpha(\boldsymbol{o}, \boldsymbol{s}) & =\frac{\gamma \mu^{2} a_{1}{ }^{2} a_{3}}{4 \sqrt{\pi}} k^{4} \int_{0}^{2 \pi} d \phi \\
& \times \int_{0}^{\pi} \sin \theta \exp \left[-\frac{k_{s}{ }^{2}\left\{a_{1}{ }^{2} \sin ^{2} \theta+a_{3}{ }^{2}(\cos \theta-1)^{2}\right\}}{4}\right] d \theta
\end{aligned}
$$

ここで（15）式より、 $k_{s}$ を $\theta$ で微分すると、（31）式が得られる。

$$
d k_{s}=k \cos \frac{\theta}{2} d \theta
$$

$\sin \theta=2 \sin (\theta / 2) \cos (\theta / 2) 、 \cos \theta=1-2 \sin ^{2}(\theta / 2)$ を踏まえ、(15) 式および（31）式を（30）式の $\sin \theta$ および $\cos \theta$ に代入する。また $\sin \theta d \theta=k_{s} d k_{s} / k^{2}$ より ${ }^{10)} 、 \alpha(\boldsymbol{o}, \boldsymbol{s})$ は（32）式のとおり表現できる。

$$
\begin{aligned}
\alpha(\boldsymbol{o}, \boldsymbol{s}) & =\frac{\sqrt{\pi} \gamma k^{2} \mu^{2} a_{1}{ }^{2} a_{3}}{2} \\
& \times \int_{0}^{2 k} \exp \left[-k_{s}{ }^{4}\left\{\left(a_{3}{ }^{2}-a_{1}{ }^{2}\right) \frac{k_{s}{ }^{2}}{16 k^{4}}+a_{1}{ }^{2} \frac{1}{4 k^{2}}\right\}\right] k_{s} d k_{s}
\end{aligned}
$$

一方、指数型の $\Phi_{n}\left(\boldsymbol{k}_{s}\right)$ を（33）式で表現する。

$$
\Phi_{n}\left(\boldsymbol{k}_{s}\right)=\frac{\mu^{2} a_{1} a_{2} a_{3}}{\pi^{2}\left\{1+\left(k_{s 1}{ }^{2} a_{1}{ }^{2}+k_{s 2}{ }^{2} a_{2}{ }^{2}+k_{s 3}{ }^{2} a_{3}{ }^{2}\right)\right\}^{2}}
$$

ガウス型の場合と同様に、 $a_{1}=a_{2}$ とする。（33）式を（25）式に 代入すると、 $\alpha(\boldsymbol{o}, \boldsymbol{s})$ は（34）式のとおり表現できる。

$$
\begin{aligned}
\alpha(\boldsymbol{o}, \boldsymbol{s}) & =2 \pi \gamma k^{4} \int_{0}^{2 \pi} d \phi \\
& \times \int_{0}^{\pi} \sin \theta \frac{\mu^{2} a_{1}{ }^{2} a_{3}}{\pi^{2}\left[1+k_{s}{ }^{2}\left\{a_{1}{ }^{2} \sin ^{2} \theta+a_{3}{ }^{2}(\cos \theta-1)^{2}\right\}\right]^{2}} d \theta
\end{aligned}
$$


ガウス型の場合と同様の変数変換を行うと、 $\alpha(\boldsymbol{o}, \boldsymbol{s})$ は（35）式の とおり表現できる。

$$
\begin{aligned}
\alpha(\boldsymbol{o}, \boldsymbol{s}) & =64 \gamma k^{10} \mu^{2} a_{1}{ }^{2} a_{3} \\
& \times \int_{0}^{2 k} \frac{k_{s}}{\left\{4 k^{4}+k_{s}{ }^{6}\left(a_{3}{ }^{2}-a_{1}{ }^{2}\right)+4 k^{2} k_{s}{ }^{4} a_{1}{ }^{2}\right\}^{2}} d k_{s}
\end{aligned}
$$

\section{3. 地震観測記録のばらつき度合いと地盤の不均質性との関係}

(5) 式の $I_{t} / I_{c}$ の関係を (4) 式に代入すると、 $\left\langle\varepsilon^{2}\right\rangle$ と $\alpha$ の関係は (36) 式となる。

$$
\left\langle\varepsilon^{2}\right\rangle+1 \approx e^{2 \alpha L}
$$

（36）式の $\alpha$ に（32）式を代入し、両辺に対数をとると、（37）式 のとおり、ガウス型による地盤の不均質性および地盤深さと地震動 のばらつきとの関係が得られる。

$\ln \left(\left\langle\varepsilon^{2}\right\rangle+1\right)=\gamma L \sqrt{\pi} k^{2} \mu^{2} a_{1}^{2} a_{3}$

$$
\times \int_{0}^{2 k} \exp \left[-k_{s}{ }^{4}\left\{\left(a_{3}{ }^{2}-a_{1}{ }^{2}\right) \frac{k_{s}{ }^{2}}{16 k^{4}}+a_{1}{ }^{2} \frac{1}{4 k^{2}}\right\}\right] k_{s} d k_{s}
$$

また、（36）式の $\alpha$ (35) 式を代入し、両辺に対数をとると、(38) 式のとおり、指数型による地盤の不均質性および地盤深さと地震動 のばらつきとの関係が得られる。

$$
\begin{aligned}
\ln \left(\left\langle\varepsilon^{2}\right\rangle+1\right) & =128 \gamma L k^{10} \mu^{2} a_{1}{ }^{2} a_{3} \\
\times & \int_{0}^{2 k} \frac{k_{s}}{\left\{4 k^{4}+k_{s}{ }^{6}\left(a_{3}{ }^{2}-a_{1}{ }^{2}\right)+4 k^{2} k_{s}{ }^{4} a_{1}{ }^{2}\right\}^{2}} d k_{s}
\end{aligned}
$$

(37) 式および (38) 式において、 $\left\langle\varepsilon^{2}\right\rangle$ は観測記録より求められる。 地盤の不均質性 $\left(\mu 、 a_{1} 、 a_{3}\right)$ が既知でかつ $\psi$ を把握できる場合、(37) 式または（38）式により求めたLについては、後述するとおり、地震 動の空間変動に影響を与える地盤深さ $L_{c}$ と見なす。

なお、本検討では Rittter et al.(1998) 8)に倣い、（37）式や（38） 式の適用条件として、(39) 式および (40) 式を満足することとする。

$$
a k \mu^{2} \ll 1
$$

$k a \geq 1$

(39) 式は $\varepsilon^{2}$ が小さく散乱の度合いが大きくない範囲を評価対象 とするために設定した周波数の上限に相当する ${ }^{10)}$ 。また (40) 式は、 地震動の空間変動の評価において、後方散乱の影響を無視すること を踏まえた条件であり、評価対象周波数の下限に相当する 10)。

\section{3. 不均質地盤モデルを用いた検証}

3 次元 FEM 不均質地盤モデルを用いた地震動シミュレーション を実施し、隣接地点間における地震動を抽出する。また、前章で求 めた地盤の不均質パラメータと隣接地点間における地震動の空間変 動との関係をシミュレーションより抽出した隣接地点間の地震動に 適用することにより、地震動の空間変動に影響を与える地盤深さに ついて考察する。

\section{1 地盤モデルと入力地震動}

本検討で使用した 3 次元不均質地盤モデルの形状を Fig. 2 に示 す。モデルのサイズは水平 2 方向を $300 \mathrm{~m}$ 、深さ方向を $200 \mathrm{~m}$ とし た。境界条件は側面を粘性境界、底面を固定境界とした。またモデ ルのメッシュサイズは $1 \mathrm{~m} \times 1 \mathrm{~m}$ とした。

地盤の平均 $\mathrm{S}$ 波速度は $300 \mathrm{~m} / \mathrm{s}$ とし、ばらつきのパターンがガウ ス型および指数型の自己相関関数に従うように $\mathrm{S}$ 波速度を変動させ た。また P 波速度は佐藤他 ${ }^{13)}$ を参考に、密度については堀川他 ${ }^{14)}$ 参考に、いずれも $\mathrm{S}$ 波速度に基づき設定した。本検討で解析対象と
した不均質パラメータのケースを Table 1 に示す。本検討では水平、 鉛直方向の相関距離 $\left(a_{1} 、 a_{3}\right)$ 、および変動係数 $\mu$ を変化させた。こ こで $a_{3}$ については $a_{1}$ の 0.1 倍、 0.2 倍、 0.5 倍、 1 倍、 2 倍の 5 種類 を設定した。 $\mu$ は基本的に 0.15 としたが、 $a_{1}$ が $30 \mathrm{~m} 、 a_{3}$ が $3 \mathrm{~m}$ の場 合のみ、 $\mu$ を 0.05、0.10とした場合についても検討した。また本検 討では初期乱数を変化させることにより、す心゙ての検討ケースにお いて 5 種類の地盤モデルを作成した。なお、モデル境界より外側の $\mathrm{S}$ 波速度は一様に $300 \mathrm{~m} / \mathrm{s}$ とした。また地盤モデル内の波動場のエ ネルギーを一定とするため、地盤の内部減衰は考慮していない。解 析に使用した地盤モデルの例として、Table 1 のケース 3-1 として 作成した不均質地盤モデルにおける側面および地表面の $\mathrm{S}$ 波速度の 分布を Fig. 3 に示す。

入力地震動はインパルス的な震動を与えることを目的に、y方向 のみに振幅を持つ加振時間 0.02 秒の三角型関数の変位波形を地盤 モデルの底面より鉛直方向に平面波入射した。また、モデル境界か らの反射波の影響を少なくする観点から、応答波の抽出は Fig. 2 の 太線で示すとおり、地盤モデル地表の中央部で $x$ 方向、 $y$ 方向ともに 長さ $100 \mathrm{~m}$ の線上の範囲とし、 $1.0 \mathrm{~m}$ 間隔で抽出地点を設定した。 また本検討では変位応答の時刻歴波形を抽出した。応答波の抽出時

\begin{tabular}{|c|c|c|c|c|c|c|c|}
\hline Case & $a_{1}$ & $a_{3}$ & $\mu$ & Case & $a_{1}$ & $a_{3}$ & $\mu$ \\
\hline $1-1$ & \multirow{5}{*}{$10 \mathrm{~m}$} & $1 \mathrm{~m}$ & \multirow{10}{*}{0.15} & $3-1$ & \multirow{7}{*}{$30 \mathrm{~m}$} & $3 \mathrm{~m}$ & \multirow{5}{*}{0.15} \\
\hline $1-2$ & & $2 \mathrm{~m}$ & & $3-2$ & & $6 \mathrm{~m}$ & \\
\hline $1-3$ & & $5 \mathrm{~m}$ & & $3-3$ & & $15 \mathrm{~m}$ & \\
\hline $1-4$ & & $10 \mathrm{~m}$ & & $3-4$ & & $30 \mathrm{~m}$ & \\
\hline $1-5$ & & $20 \mathrm{~m}$ & & 3-5 & & $60 \mathrm{~m}$ & \\
\hline $2-1$ & \multirow{5}{*}{$20 \mathrm{~m}$} & $2 \mathrm{~m}$ & & 3-6 & & $3 \mathrm{~m}$ & 0.05 \\
\hline $2-2$ & & $4 \mathrm{~m}$ & & 3-7 & & $3 \mathrm{~m}$ & 0.10 \\
\hline 2-3 & & $10 \mathrm{~m}$ & & 4-1 & \multirow{5}{*}{$40 \mathrm{~m}$} & $4 \mathrm{~m}$ & \multirow{5}{*}{0.15} \\
\hline 2-4 & & $20 \mathrm{~m}$ & & 4-2 & & $8 \mathrm{~m}$ & \\
\hline $2-5$ & & $40 \mathrm{~m}$ & & 4-3 & & $20 \mathrm{~m}$ & \\
\hline & & & & 4-4 & & $40 \mathrm{~m}$ & \\
\hline & & & & 4-5 & & $80 \mathrm{~m}$ & \\
\hline
\end{tabular}
間はモデル底面より入力を開始してから約 2.5 秒間とした。

ガウス型の不均質パターンでケース 3-1 の不均質地盤モデルを対

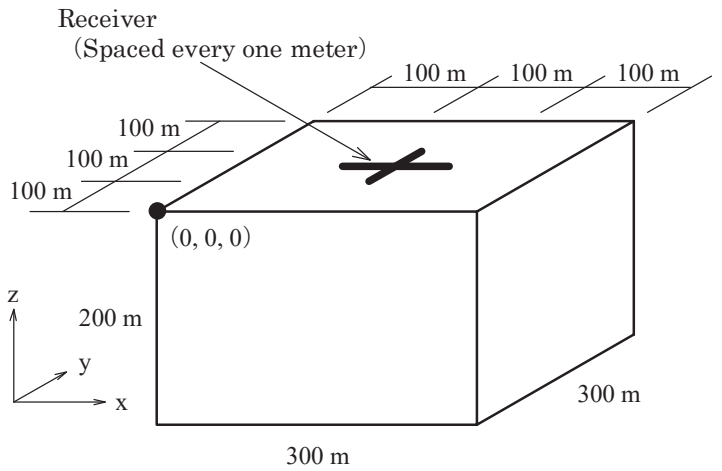

Fig. 2 The configuration of 3-D heterogeneous soil model and receivers of the response wave

Table 1 Heterogeneous parameter cases of 3-D soil models 

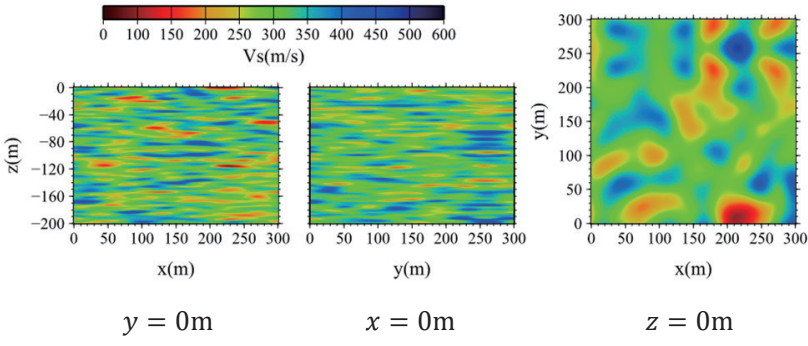

(a) Gaussian type
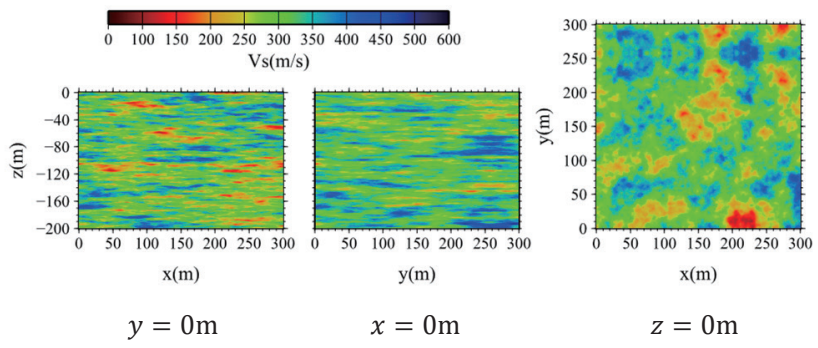

(b) Exponential type

Fig. 3 Examples of heterogeneous soil models (Case 3-1)

象に、Fig. 2 に示寸座標で $(x, y, z)=(100 \mathrm{~m}, 150 \mathrm{~m}, 0 \mathrm{~m})$ の波形と $(105 \mathrm{~m}, 150 \mathrm{~m}, 0 \mathrm{~m})$ および $(150 \mathrm{~m}, 150 \mathrm{~m}, 0 \mathrm{~m})$ の波形の平均と残差よ り、離間距離が $5 \mathrm{~m}$ および $50 \mathrm{~m}$ の応答波形のコヒーレントな成分 $\langle u\rangle$ およ゙ばらつき成分 $u_{f}$ を計算した例を Fig. 4 に示す。離間距離が $5 \mathrm{~m}$ の波形に比べ離間距離が $50 \mathrm{~m}$ の波形では、ばらつき成分の初動 振幅が大きくなっている。Fig. 4 に示す $\langle u\rangle$ おびu化のパワースペク トルを Fig. 5 に示す。離間距離が $5 \mathrm{~m}$ の場合はほぼ全周期帯にわた り、〈u〉のパワースペクトルが $u_{f}$ のパワースペクトルを上回っている のに対し、離間距離が $50 \mathrm{~m}$ の場合は $5 \mathrm{~Hz}$ 付近より高周波数側でほ ぼ同レベルとなっており、離間距離が大きくなるほどu ペクトルが相対的に大きくなるのが確認できる。

\section{2 地震動の空間変動に影響を与える地盤深さの推定}

Table 1 に示した各検討ケースについて、初期乱数が異なる 5 種 類の不均質地盤モデルの地表において抽出したすべての応答波のう ち、離間距離が $10 \mathrm{~m} 、 20 \mathrm{~m} 、 30 \mathrm{~m} 、 40 \mathrm{~m} 、 50 \mathrm{~m}$ となる観測点ペアよ り振幅の平均のパワースペクトルおよびばらつき成分のパワースペ クトルの比の平均 $\left\langle\varepsilon^{2}\right\rangle$ を計算し、波動伝播方向（鈆直方向）の相関距 離と波数の積 $k a_{3}$ と $\ln \left(\left\langle\varepsilon^{2}\right\rangle+1\right)$ との関係を整理した。不均質パター ンをガウス型とした場合の $k a_{3}$ と $\ln \left(\left\langle\varepsilon^{2}\right\rangle+1\right)$ との関係を Fig. 6 に示 す。 $k a_{3}$ の值が大きくなるほど $\ln \left(\left\langle\varepsilon^{2}\right\rangle+1\right)$ も大きくなるが、ほとんど のケースにおいて、 $k a_{3}$ がある程度大きくなると $\ln \left(\left\langle\varepsilon^{2}\right\rangle+1\right)$ が大き くなる度合いが低下寸る傾向が見られる。また観測点間の離間距離 が小さく、 $\mu$ が小さいほど、 $\ln \left(\left\langle\varepsilon^{2}\right\rangle+1\right)$ もさくなるのが確認できる。 なお、地盤の不均質パターンを指数型とした場合について、各検討 ケースでガウス型の $\ln \left(\left\langle\varepsilon^{2}\right\rangle+1\right)$ と比較した結果、両者に大きな差異 は見られなかった。この傾向は秋田他(2013)15)による不均質地盤モ デルを用いた地震動シミュレーションにおいても指摘されている。

（37）式および（38）式のLは地震動の伝播距離で、本検討では地 盤モデルの深さに相当する。一方、隣接地点間の地震動の空間変動 は、Lの中でも表層付近の地盤物性の影響が大きく、深部の地盤物性 が地震動の空間変動に与える影響は小さいと考えられる。また筆者

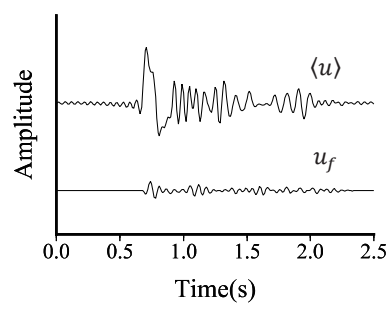

(a) Separation distance : $5 \mathrm{~m}$

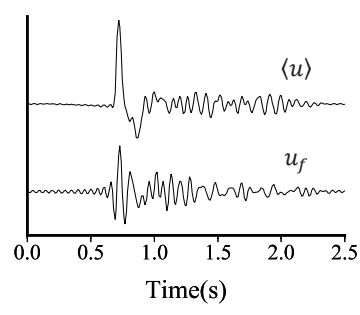

(b) Separation distance : $50 \mathrm{~m}$
Mean waveform

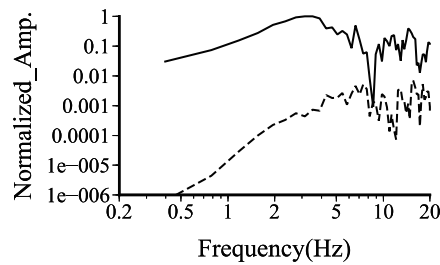

(a) Separation distance : $5 \mathrm{~m}$

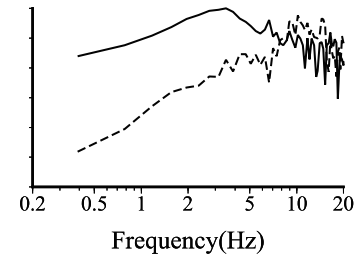

(b) Separation distance : $50 \mathrm{~m}$
Fig. 5 Examples of power spectra of mean waveforms and residual waveforms

らは既往の地震動シミュレーション解析において、地盤モデルをあ る深度より深くしても、隣接地点間の地震動の空間変動特性に大き な変化が見られなくなることを確認し、隣接地点間の地震動の空間 変動に影響を与える地盤深さ $L_{c}$ が存在するのではないかと指摘して

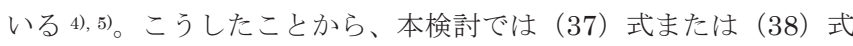
による $\ln \left(\left\langle\varepsilon^{2}\right\rangle+1\right)$ の評価において、Lは地盤モデルの深さ $(200 \mathrm{~m})$ ではなく、地震動シミュレーションより求めた $\ln \left(\left\langle\varepsilon^{2}\right\rangle+1\right)$ との 2 乗 誤差を最小にするように付与し、そのときの $L$ が地震動の空間変動 に影響を与える地盤深さ $L_{c}$ に相当するとして取り扱うこととした。

2 乗誤差の計算にあたっては、（39）式および（40）式を満足する こと、また地震動の散乱の度合いが弱い $(\varepsilon<1)$ 範囲となるように、 評価対象の $\mathrm{ka}_{3}$ の領域を設定した。これらの条件を踏まえ、全検討ケ 一スにおいて、評価対象周波数帯域として $5 \mathrm{~Hz}$ 以上を確保した。た だし $a_{3}$ が小さいケース 1-1、1-2、2-1、3-1、3-6、3-7 については、 $k a_{3} \geq 1$ の範囲では散乱の度合いが強くなることから、 $k a_{3} \leq 1$ にお いて、評価対象周波数帯域として $5 \mathrm{~Hz}$ を確保した。

ここで（37）式および（38）式を適用するにあたり、散乱角 $\psi$ の 閾值を設定する必要がある。河原(1997) ${ }^{12)}$ は数值解析に基づき散乱 減衰を評価した既往の研究例えば 16), 17)を整理しており、散乱減衰に寄 与しない前方散乱の角度の閾值、寸なわち地震波の振幅を支配する 散乱角がおおむ称 $10^{\circ}<\psi<40^{\circ}$ の範囲に収まるとしている。

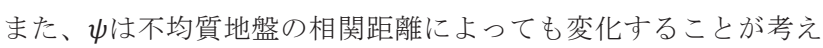
られる。鉛直方向の相関距離に比べ、水平方向の相関距離が大きい 不均質地盤では、速度構造が平行成層地盤に近い形状となり、地震 波がより鉛直方向に伝播し、 $\psi$ が相対的に小さくなることが推測さ れる。Roth et al.(1993)17) は 2 次元不均質地盤モデルを用いた地震 動シミュレーションにより、水平方向の相関距離の大小と $\psi$ との関 係について評価している。このシミュレーション結果によると、水 

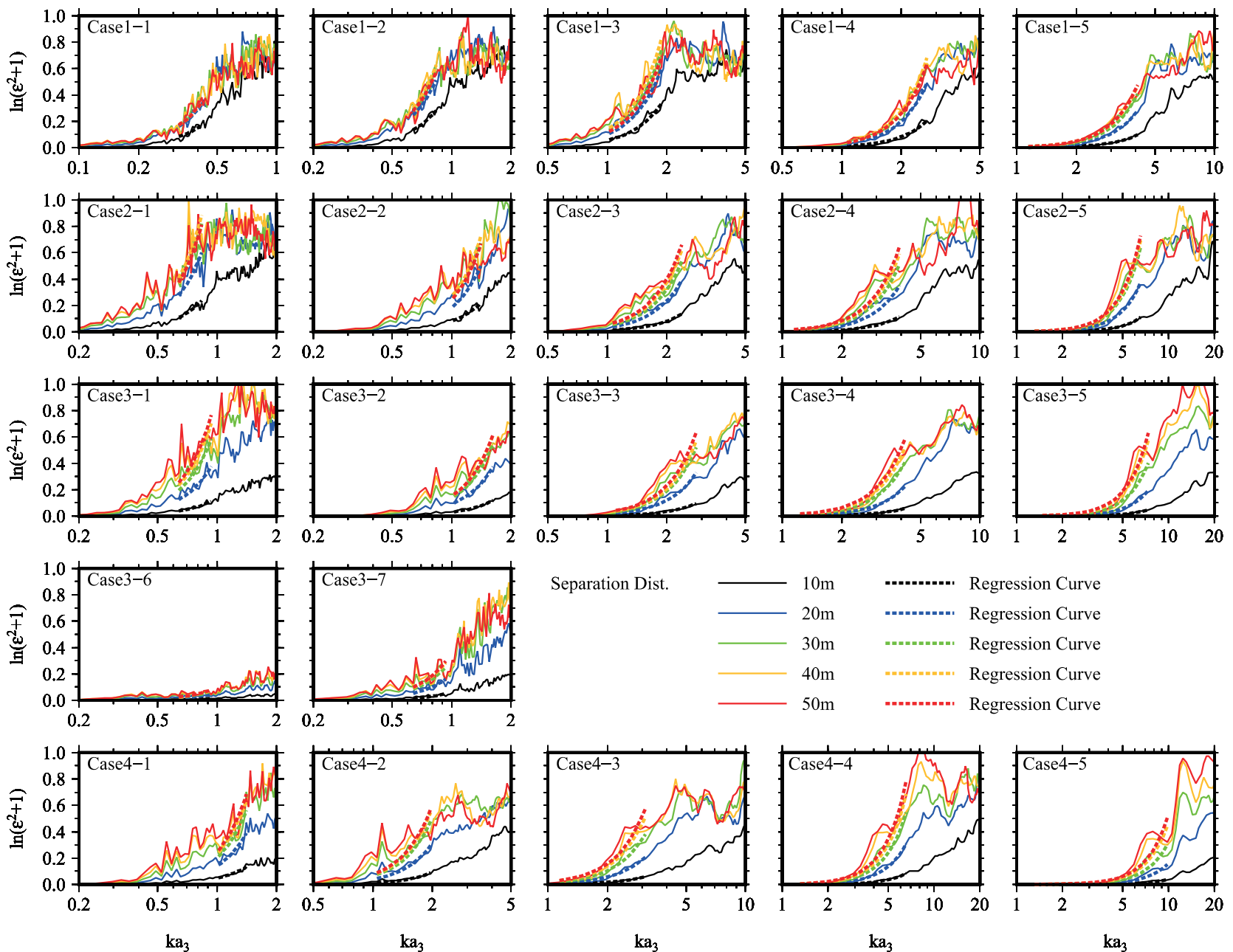

Fig. 6 Relations between $\ln \left(\left\langle\varepsilon^{2}\right\rangle+1\right)$ and $k a_{3}$ (Gaussian type)

平方向と鉛直方向の相関距離の比 $a_{3} / a_{1}$ が 1 の場合は $\psi$ が $20^{\circ} \sim 30^{\circ}$ の範囲に評価されているのに対し、 $a_{3} / a_{1}$ が $1 / 3$ の場合は $\psi$ が $20^{\circ}$ 前 後に、 $a_{3} / a_{1}$ が $1 / 10$ の場合は $\psi$ が $20^{\circ}$ 前後から $20^{\circ}$ 以下の範囲とな っており、 $a_{3} / a_{1}$ が小さくなるとともに $\psi$ む小さく評価されている。 以上を踏まえ、本検討では Fig. 7 に示すように、 $a_{3} / a_{1}$ の值に応 じて変化させた $\mathrm{A} \sim \mathrm{C}$ の 3 種類の $\psi$ のタイプを仮定し、地震動の空 間変動に影響を与える地盤深さ $L_{c}$ を推定した。

ガウス型および指数型の不均質地盤モデルのうち、 $a_{3} / a_{1}$ が 0.5 に 相当するケース 1-3、2-3、3-3、4-3 を対象に、Fig. 7 のタイプ A〜 $\mathrm{C}$ で観測点間の離間距離ごとに $L_{c}$ を推定した結果を Fig. 8 に示す。 本検討では地盤モデルの深さを $200 \mathrm{~m}$ としたため、Fig. 8 において

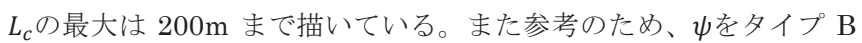
とし、 $\ln \left(\left\langle\varepsilon^{2}\right\rangle+1\right)$ を(37) 式で回帰した結果を Fig. 6 に点線で示す。 Fig. 8 によると、観測点間の離間距離が大きくなるほど $L_{c}$ が大きく なる傾向が確認できる。

$L_{c}$ の推定結果について考察するため、Fig. 8 に示すケース 3-3 を 対象に、不均質地盤モデルの地盤深さを $10 \sim 200 \mathrm{~m}$ において $10 \mathrm{~m}$ 単位で変化させ、地震動シミュレーションにより $\ln \left(\left\langle\varepsilon^{2}\right\rangle+1\right)$ を計算 し、地盤モデルの深さと $\ln \left(\left\langle\varepsilon^{2}\right\rangle+1\right)$ との関係を分析した。ここで地 盤モデルは地表を基準として深さを変化させた。離間距離 $30 \mathrm{~m}$ を 対象に、地盤深さを $20 \mathrm{~m}$ 間隔で変化させたときの $\ln \left(\left\langle\varepsilon^{2}\right\rangle+1\right)$ の結
果を Fig. 9 に示す。ガウス型、指数型のいずれの不均質パターンに おいても、地盤深さを深く設定するほど $\ln \left(\left\langle\varepsilon^{2}\right\rangle+1\right)$ は大きくなるが、 地盤深さが $120 \mathrm{~m}$ より深くなると、 $\ln \left(\left\langle\varepsilon^{2}\right\rangle+1\right)$ の変化が小さくなっ ている。Fig. 8 の離間距離が $30 \mathrm{~m}$ における $L_{c}$ の推定結果と比較する と、ガウス型の不均質地盤モデルでは $L_{c}$ と Fig. 9 で $\ln \left(\left\langle\varepsilon^{2}\right\rangle+1\right)$ が安 定する地盤深さがほぼ対応している。しかし指数型の不均質地盤モ デルでは、 $L_{c}$ が約 $50 \mathrm{~m}$ とかなり小さく推定されている。

地震動シミュレーションにおいてはガウス型および指数型の不均 質地盤モデルの間で $\ln \left(\left\langle\varepsilon^{2}\right\rangle+1\right)$ に大きな差異は見られない。一方、 相関距離が同じ場合、指数型の評価式である（38）式はガウス型の 評価式である（37）式に比べ、 $\ln \left(\left\langle\varepsilon^{2}\right\rangle+1\right)$ を大きく評価する。 河原(1997) ${ }^{12}$ ) は複数の不均質パターンを対象に、媒質の変動の大

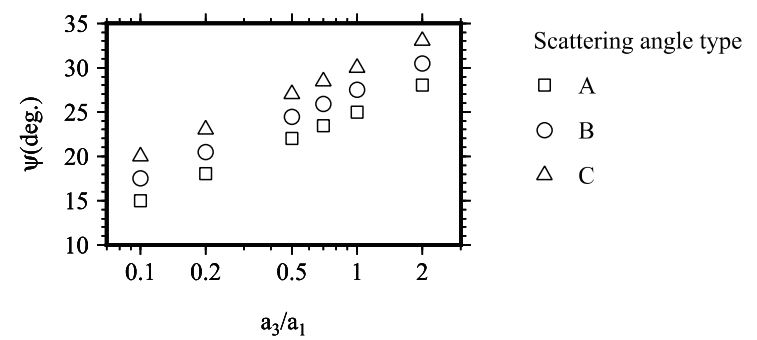

Fig. 7 Relations of the ratio of $a_{3}$ to $a_{1}$ and $\psi$ 

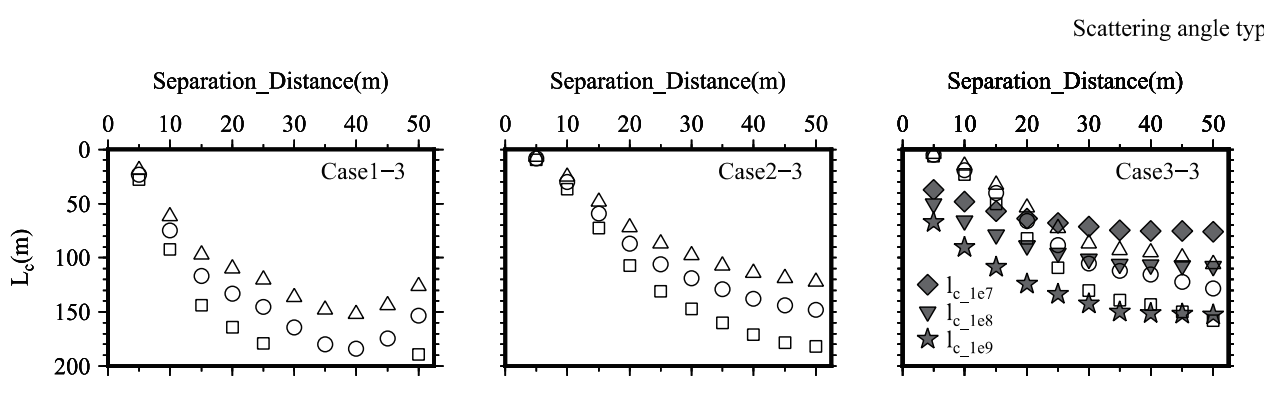

$\square \mathrm{A} \quad \mathrm{B} \quad \triangle \mathrm{C}$

(a) Gaussian type
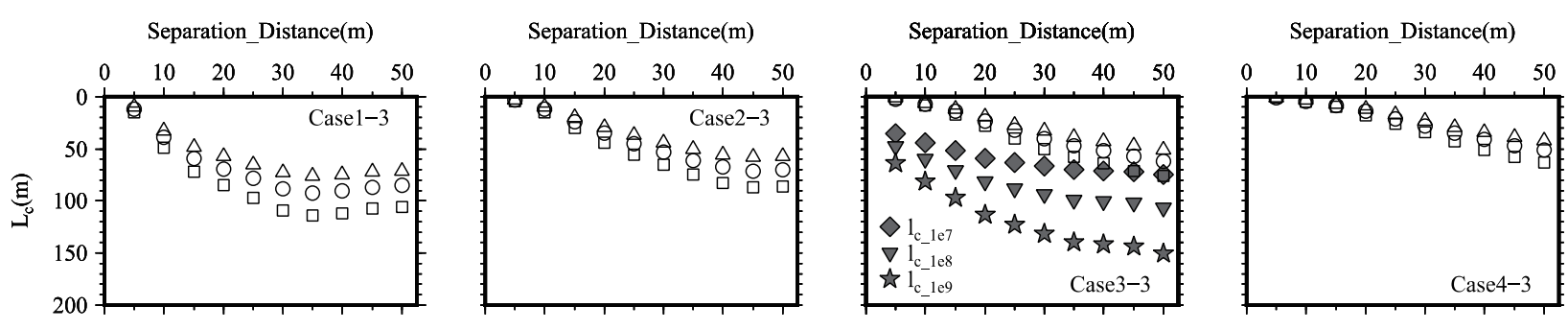

(b) Exponential type

Fig. 8 Estimation of $L_{c}$ for each separation distance

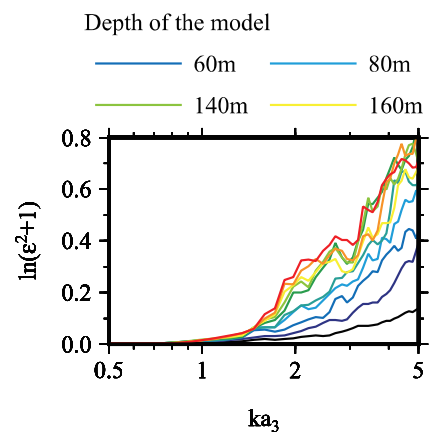

(a) Gaussian type

Fig. $9 \ln \left(\left\langle\varepsilon^{2}\right\rangle+1\right)$ of different depths of soil models

(Case3-3 Separation distance : $30 \mathrm{~m}$ )

きさを比較している。この中で、指数型の不均質パターンはガウス 型の不均質パターンに比べ、高周波数帯域の変動成分が大きいこと を示している。本検討では地震動の散乱の度合いが弱い $(\varepsilon<1)$ 周 波数帯域を評価対象とするために、 $\ln \left(\left\langle\varepsilon^{2}\right\rangle+1\right)$ から $L_{c}$ を推定する過 程において、Fig. 6 の点線で示すとおり $k a_{3}$ に上限を設定し、高周波 数側を評価対象から除外した。このことが、(38) 式による指数型の 不均質地盤モデルにおける $L_{c}$ の推定結果と、Fig. 9 で $\ln \left(\left\langle\varepsilon^{2}\right\rangle+1\right)$ が 安定する地盤深さとの間で差異が見られる原因となった可能性があ る。 $L_{c}$ の推定において $\ln \left(\left\langle\varepsilon^{2}\right\rangle+1\right)$ の評価対象とする $k a_{3}$ の範囲につい ては、今後も更なる検討が必要であると考えられる。

深さ $10 \mathrm{~m}$ の地盤モデルにおける $\ln \left(\left\langle\varepsilon^{2}\right\rangle+1\right)$ に対する深さ $\operatorname{lm}$ の地 盤モデルの $\ln \left(\left\langle\varepsilon^{2}\right\rangle+1\right)$ の昇率 $\xi(l)$ を（41）式で定義する。

$$
\xi(l)=\int_{f_{1}}^{f_{2}}\left\{\ln \left(\left\langle\varepsilon_{l}{ }^{2}\right\rangle+1\right)-\ln \left(\left\langle\varepsilon_{10}{ }^{2}\right\rangle+1\right)\right\} d f
$$

ここで、 $f_{1}:$ Fig. 6 で回帰対象とした周波数の下限 $f_{2}$ : Fig. 6 で回輀対象とした周波数の上限 $\varepsilon_{l}:$ 深さ $l(\mathrm{~m})$ の不均質地盤モデルに対する $\varepsilon$

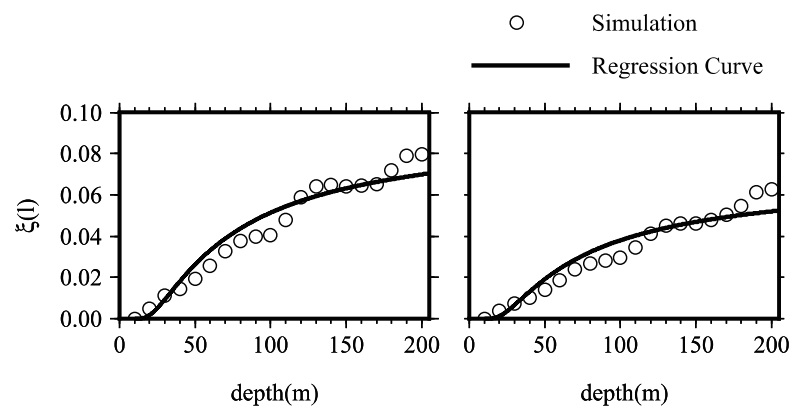

$\begin{array}{ll}\text { (a) Gaussian type } & \text { (b) Exponential type }\end{array}$

Fig. 10 Relations between the depth of soil models $l$ and $\xi(l)$ (Separation distance : $30 \mathrm{~m}$ )

$\varepsilon_{10}$ : 深さ $10 \mathrm{~m}$ の不均質地盤モデルに対する $\varepsilon$

離間距離が $30 \mathrm{~m}$ の場合を対象に、地盤モデルの深さを $10 \sim 200 \mathrm{~m}$ において $10 \mathrm{~m}$ 単位で変化させたときの $\xi(l)$ の結果を Fig. 10 に○印 で示す。地盤モデルが深くなるとともに $(l)$ がほぼ単調に上昇する が、上昇の度合いは地盤モデルが深くなるとともに低下寸る。

離間距離が $5 \mathrm{~m} \sim 50 \mathrm{~m}$ における $5 \mathrm{~m}$ 間隔を対象に、 $(l)$ を (42) 式に示す曲線で回帰する。

$$
\xi(l)=b_{1}(\delta)(0.1-1 / l)^{b_{2}(\delta)}
$$

ここで $b_{1}(\delta) 、 b_{2}(\delta)$ は回帰係数で、離間距離 $\delta$ ごとに設定した。 $\delta$ が $30 \mathrm{~m}$ の場合を対象に、 $(l)$ を(42) 式により回帰した結果を Fig. 10 に実線で示す。また本検討では、（42）式における回帰式の傾きが $10^{-7} 、 10^{-8} 、 10^{-9}$ となる地盤モデルの深さ $l_{c_{-} 1 e 7} 、 l_{c_{-} 1 e 8} 、 l_{c_{-} 1 e 9}$ を $\xi(l)$ が

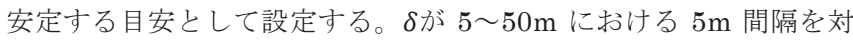
象に $l_{C_{-} 1 e 7 、} l_{c_{-} 1 e 8} 、 l_{c_{-} 1 e 9}$ を求めた結果を Fig. 8 のケース 3-3 の結果に 重悋て示す。 $\delta$ が大きくなるにしたがい $l_{c_{-} 1 e 7} 、 l_{c_{-} 1 e 8} 、 l_{c_{-} 1 e 9}$ はいずれ も大きくなっている。この傾向は、（37）式および（38）式により推 定した $L_{c}$ の結果においても同様に確認できる。 


\section{4. 観測記録への適用}

(37) 式および (38) 式を隣接地点間の実観測記録に見られる地震 動の空間変動に適用し、表層地盤の不均質パラメータを推定する。 本検討では東京大学生産技術研究所旧西千葉キャンパスに整備され ていた千葉アレイ観測施設の記録を使用する。

\section{1 千葉アレイ観測施設と解析対象観測記録}

千葉アレイ観測施設のうち、本検討において観測記録を使用した 観測点の配置図を Fig. 11 に示寸 18)。本検討では Fig. 11 の中から 2 観測点の離間距離が $5 \mathrm{~m} 、 10 \mathrm{~m} 、 15 \mathrm{~m} 、 21 \mathrm{~m} 、 30 \mathrm{~m}$ となる組み合わ せを地震動の空間変動の評価対象とした。各離間距離に該当する観 測点の組み合わせを Table 2 に示す。

千葉アレイ観測施設における $\mathrm{S}$ 波速度構造 18 )を Table 3 に示す。 第 2 層と第 3 層は $\mathrm{S}$ 波速度が同じ值であるが、 $\mathrm{P}$ 波速度が異なる ${ }^{18)}$ ことから層を分離した。また $\mathrm{S}$ 波速度が $420 \mathrm{~m} / \mathrm{s}$ の層については、 深さ方向に対する不均質性の変化を検証するため、本検討では第 4 層と第 5 層に分離した。

解析対象とした観測記録の地震諸元を Table 4 に、震央分布図を Fig. 12 に示寸。本検討では解析対象地震の選定条件として、(1)地震 規模 $\left(\mathrm{M}_{\mathrm{J}}\right) 4.5$ 以上、(2)震源深さ $80 \mathrm{~km}$ 以上、(3)見かけの入射角 $40^{\circ}$ 以内、(4)最大加速度 $100 \mathrm{~cm} / \mathrm{s}^{2}$ 以内の 4 種類を設定した。(1)は観測 記録にノイズの影響が多く含まれないことを目的にしたものである。 (2)は P 波初動の振幅による影響が少なく、 $\mathrm{S}$ 波初動の波形を解析対 象として適切に抽出できることを目的とした。(3)震源からの直達 波ができるだけ鉛直入射された観測記録を解析対象とするために設 定したもので、震源から観測点までの地盤構造をJ-SHIS の地盤モ デル（V2） 19)に基づき平行成層で仮定した場合、S 波速度 $420 \mathrm{~m} / \mathrm{s}$ の層における入射角は $4^{\circ}$ 以内と想定される。(4)は観測記録に地盤 の非線形性の影響が含まれないことを考慮したことによる。

本検討では、目視で $\mathrm{S}$ 波初動より 5.12 秒間を抽出した波形を解 析対象とする。また、NS、EW の観測記録を RD、TR 方向に方位
変換した。Table 4 に示寸解析対象地震の観測記録より $\mathrm{S}$ 波初動を 抽出し、隣接する 2 観測点間の水平方向（RD、TR 成分）のコヒー レント成分 $\langle u\rangle$ のパワースペクトルとばらつき成分 $u_{f}$ のパワースペ クトルの比の平均 $\left\langle\varepsilon^{2}\right\rangle$ より $\ln \left(\left\langle\varepsilon^{2}\right\rangle+1\right)$ を求めた。離間距離ごとに $\ln \left(\left\langle\varepsilon^{2}\right\rangle+1\right)$ を描いた結果を Fig. 13 に示す。周波数が高くなるほど $\ln \left(\left\langle\varepsilon^{2}\right\rangle+1\right)$ が大きくなるが、周波数がある程度高くなると $\ln \left(\left\langle\varepsilon^{2}\right\rangle+\right.$ 1)が大きくなる度合いは低下寸る。また低周波数側では 2 観測点間 の離間距離が小さいほど、 $\ln \left(\left\langle\varepsilon^{2}\right\rangle+1\right)$ が小さくなる傾向が見られる。

\section{2 地盤の不均質パラメータの推定}

Fig. 13 の結果と、（37）式または（38）式により評価した結果と の誤差の 2 乗和が最小となるように、グリッドサーチにより不均質 地盤の相関距離 $a_{1} 、 a_{3}$ およ゙地震動の空間変動に影響を与える地盤 深さ $L_{c}$ を推定する。

（37）式または（38）式の適用にあたり、評価対象とする周波数の 範囲として（39）式および（40）式を考慮する。ただし（40）式に 基づき $k a_{3} \geq 1$ を満足させた場合、散乱の度合いが強い周波数帯を解 析対象と寸ることになる。本検討では評価対象とする周波数帯をで きるだけ広くする観点から、 $k a_{3} \leq 1$ に相当する周波数も解析対象の 範囲にすることを許容し、周波数の下限を $5 \mathrm{~Hz}$ に設定した。また地 震動の散乱の度合いが弱い範囲を対象とする必要があることから、 Fig. 13 で $\ln \left(\left\langle\varepsilon^{2}\right\rangle+1\right)$ が頭打ちとなる手前の周波数を目視で判断し、 解析対象周波数の上限を $11 \mathrm{~Hz}$ に設定した。

地盤の不均質パラメータの探索範囲を Table 5 に示す。 $a_{1} 、 a_{3}$ は 各層で個別の值となることを許容した。 $a_{1}$ の取りうる值は $10 \mathrm{~m}$ 、 $20 \mathrm{~m} 、 30 \mathrm{~m} 、 40 \mathrm{~m}$ とし、 $a_{3}$ の取りうる值は $a_{1}$ の 0.1 倍、0.2 倍、 0.5 倍、0.7 倍、 1.0 倍、 2.0 倍とした。 $\mu$ にいては現地の PS 検層デー タが入手できていないことから、本検討では $0.15 、 0.2 、 0.25$ の 3 種類を仮定した。また予備解析の結果、 $\mu$ は各層でほとんど差異が見 られなかったことから、本検討では全ての層で同じ值となるように 設定した。なお、散乱角の閾值 $\psi$ は Fig. 7 に示寸タイプ B とした。

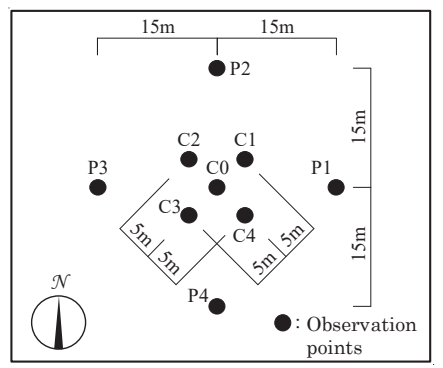

Fig. 11 Location of observation points on the Chiba Array
Table 2 Separation distances and pairs of observation points used in this study

\begin{tabular}{cl}
\hline $\begin{array}{c}\text { Separation } \\
\text { distance }(\mathrm{m})\end{array}$ & Pairs of observation points \\
\hline 5 & C0-C1, C0-C2, C0-C3, C0-C4 \\
\hline 10 & C1-C3, C2-C4 \\
\hline 15 & C0-P1, C0-P2, C0-P3, C0-P4 \\
\hline 21 & P1-P2, P1-P4, P2-P3, P3-P4 \\
\hline 30 & P1-P3, P2-P4 \\
\hline
\end{tabular}

Table 4 Seismic parameters used in this study

\begin{tabular}{cccccc}
\hline No. & Date & Epicenter & $\mathrm{M}_{J}$ & $\begin{array}{c}\text { Epicentral } \\
\text { distance }(\mathrm{km})\end{array}$ & $\begin{array}{c}\text { Depth } \\
(\mathrm{km})\end{array}$ \\
\hline 1 & $1983 / 02 / 27$ & SOUTHERN KANTO & 6.0 & 35.1 & 72 \\
\hline 2 & $1985 / 10 / 04$ & SOUTHERN IBARAKI PREF & 6.1 & 27.8 & 78 \\
\hline 3 & $1985 / 11 / 06$ & SOUTHERN BOSO PENINSULA & 5.1 & 31.8 & 63 \\
\hline 4 & $1988 / 03 / 18$ & TOKYO PREF & 6.0 & 42.2 & 96 \\
\hline 5 & $1992 / 02 / 02$ & TOKYO BAY REGION & 5.9 & 52.4 & 92 \\
\hline
\end{tabular}

Table 3 Subsurface S-wave velocity

\begin{tabular}{ccc}
\multicolumn{3}{c}{ structure on the Chiba Array } \\
No. & $\begin{array}{c}\text { Thickness } \\
(\mathrm{m})\end{array}$ & $\begin{array}{c}\text { S-wave } \\
\text { velocity }(\mathrm{m} / \mathrm{s})\end{array}$ \\
\hline 1 & 5 & 140 \\
\hline 2 & 10 & 320 \\
\hline 3 & 9 & 320 \\
\hline 4 & 40 & 420 \\
\hline 5 & - & 420 \\
\hline
\end{tabular}

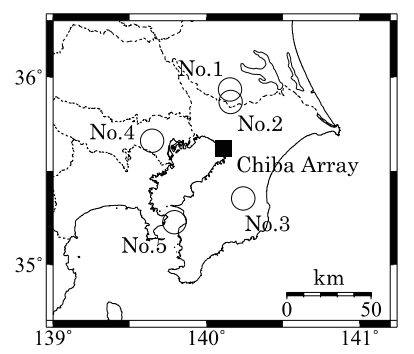

Fig. 12 Epicenter distribution used in this study 
本検討では $L_{c}$ を推定するにあたり、Fig. 14 に灰色の線で示すとお り探索範囲を設定した。この探索範囲は Fig. 8 の結果を含め、Table 1 に示寸不均質地盤モデルを用いた地震動シミュレーションより推 定した $L_{c}$ の特徵を踏まえ、離間距離が大きくなるほど $L_{c}$ の探索範囲 の上限を大きく設定した。Fig. 7 における散乱角のタイプ B により $\psi$ を設定したときの $L_{c}$ の推定結果を不均質パターンごとに Fig. 14 にあわせて示す。観測点間の離間距離が大きくなるとともに $L_{c}$ も きくなっている。また $L_{c}$ の值は一部を除き、探索範囲の上限に到達 しない範囲で推定されていることから、前章の地震動シミュレーシ ヨンで評価した離間距離と $L_{c}$ との関係とおおむ称同様の傾向を示し ていると解釈することができる。なお、 $\mu$ の違いに伴う $L_{c}$ の推定結果 に大きな差異は認められない。

不均質パターンごとに各層の相関距離を推定した結果を Table 6 に示す。また Table 6 のうち、ガウス型の不均質パターンで $\mu$ を 0.15 としたときの $\ln \left(\left\langle\varepsilon^{2}\right\rangle+1\right) を(37)$ 式により回帰した結果を Fig. 13 に 点線で示す。Table 6 によると、相関距離はガウス型の不均質パタ ーンに比べて指数型の不均質パターンの方が、全体的に小さく評価

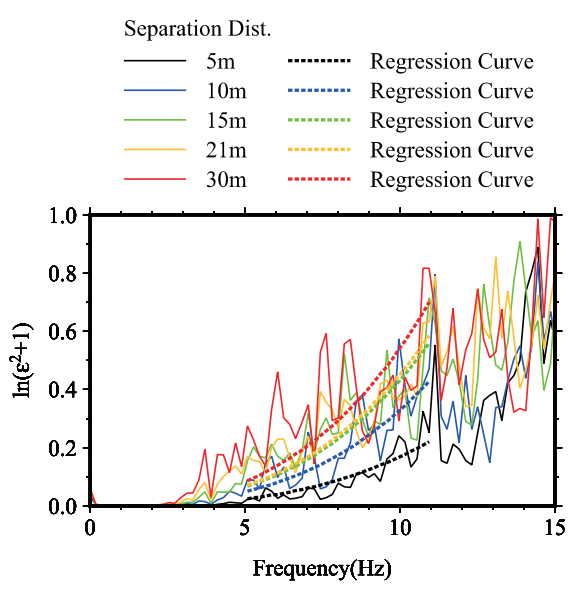

Fig. 13 Relations between frequency and $\ln \left(\left\langle\varepsilon^{2}\right\rangle+1\right)$
されている。これは、（37）式に比べて（38）式の方が $\ln \left(\left\langle\varepsilon^{2}\right\rangle+1\right)$ を 大きく評価寸る傾向にあることが影響していると考えられる。なお、 本検討では $\mathrm{S}$ 波速度が $420 \mathrm{~m} / \mathrm{s}$ の層を第 4 層、第 5 層に分割し、個 別に $a_{1}$ および $a_{3}$ を推定したが、いずれの結果においても 2 つの層間 で大きな差異は見られない。

$\mu$ と $a_{1}$ および $a_{3}$ を比較すると、一部を除き、 $\mu$ が大きくなるほど $a_{1}$ および $a_{3}$ が小さくなる傾向が見られる。 $\mu 、 a_{1}$ および $a_{3}$ は、いずれも 值が大きくなると、地震動の空間変動を大きく評価することになる。 $\mu$ が大きくなるとともに $a_{1} 、 a_{3}$ が小さくなるのは、これらのパラメー タが互いにトレードオフの関係にあるためと考えられる。ただし実 地盤においては PS 検層等の地盤調查により $\mu$ を把握することが可 能であることから、 $a_{1} 、 a_{3}$ の推定結果も安定すると考えられる。

$a_{1}$ と $a_{3}$ を比較すると、 $\mu$ の值に関係なく、いずれの推定結果におい ても $a_{1}$ の方が大きく評価されている。この傾向は、鉛直方向の相関 距離が水平方向の相関距離よりも大きいという既往の研究における 指摘例え侍3) とも対応している。

なお、観測記録には鉛直入射に近い地震波の他に、斜め入射に伴 う変換波等も含まれると考えられる。本検討ではこうした鉛直入射 以外の成分の影響を考慮していないことから、地盤の不均質パラメ ータの值を過大評価した可能性がある。不均質パラメータの評価精 度を向上させるためには、観測記録に含まれる鉛直入射波以外の影 響をできるだけ除去するための工夫が必要である。

\section{5.まとめ}

隣接地点間における地震動の空間変動特性および地震動の空間変 動を支配する表層地盤の深さについて、散乱理論に基づき考察した。 以下に本検討の結論を示す。

（1）地盤の不均質性がガウス型および指数型の自己相関関数に従 うと仮定し、隣接地点間の地震動の空間変動を表層地盤にお ける $\mathrm{S}$ 波速度の変動分の相関距離、変動係数、地震波の散乱 角および伝播距離をパラメータとする積分方程式で表現した。

Table 5 Search areas of heterogeneous parameters for each layer

\begin{tabular}{|c|c|c|}
\hline$a_{1}(\mathrm{~m})$ & $a_{3}(\mathrm{~m})$ & $\mu$ \\
\hline 10 & $1.0,2.0,5.0,7.0,10.0,20.0$ & 0.15 \\
\hline 20 & $2.0,4.0,10.0,14.0,20.0,40.0$ & \\
\hline 30 & $3.0,6.0,15.0,21.0,30.0,60.0$ & (same value \\
\hline 40 & $4.0,8.0,20.0,28.0,40.0,80.0$ & for each layer) \\
\hline
\end{tabular}

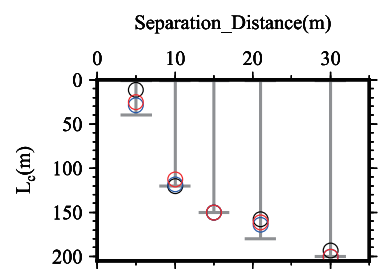

(a) Gaussian type

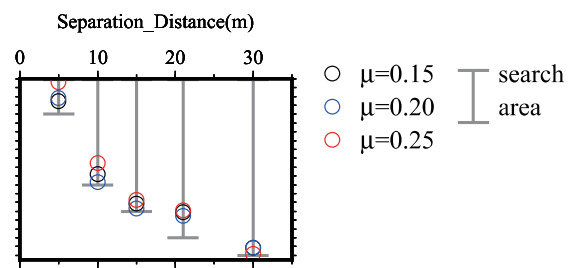

(b) Exponential type

Fig. 14 Estimation of $L_{c}$ at each separation distance

Table 6 Correlation distance estimation of subsurface soil on the Chiba Array

(a) Gaussian type

\begin{tabular}{cccccccc}
\hline & \multicolumn{2}{c}{$\mu=0.15$} & \multicolumn{2}{c}{$\mu=0.20$} & \multicolumn{2}{c}{$\mu=0.25$} \\
\hline No. & $a_{1}(\mathrm{~m})$ & $a_{3}(\mathrm{~m})$ & $a_{1}(\mathrm{~m})$ & $a_{3}(\mathrm{~m})$ & $a_{1}(\mathrm{~m})$ & $a_{3}(\mathrm{~m})$ \\
\hline 1 & 20 & 10 & 20 & 4 & 10 & 2 \\
\hline 2 & 20 & 14 & 20 & 10 & 20 & 10 \\
\hline 3 & 20 & 10 & 20 & 10 & 20 & 10 \\
\hline 4 & 20 & 10 & 20 & 10 & 20 & 4 \\
\hline 5 & 30 & 15 & 20 & 10 & 30 & 6 \\
\hline
\end{tabular}

(b) Exponential type

\begin{tabular}{cccccccc}
\hline & \multicolumn{2}{c}{$\mu=0.15$} & \multicolumn{2}{c}{$\mu=0.20$} & \multicolumn{2}{c}{$\mu=0.25$} \\
\hline No. & $a_{1}(\mathrm{~m})$ & $a_{3}(\mathrm{~m})$ & $a_{1}(\mathrm{~m})$ & $a_{3}(\mathrm{~m})$ & $a_{1}(\mathrm{~m})$ & $a_{3}(\mathrm{~m})$ \\
\hline 1 & 10 & 5 & 10 & 5 & 10 & 5 \\
\hline 2 & 20 & 10 & 10 & 5 & 10 & 2 \\
\hline 3 & 20 & 10 & 20 & 4 & 20 & 4 \\
\hline 4 & 20 & 10 & 30 & 6 & 20 & 4 \\
\hline 5 & 20 & 10 & 30 & 6 & 20 & 4 \\
\hline
\end{tabular}


（2）３次元不均質地盤モデルを用いた地震動シミュレーションの 結果に（1）の積分方程式を適用し、隣接地点間の地震動の空 間変動に影響を与える地盤深さ $L_{c}$ を推定した。その結果、観測 点間の離間距離が大きくなるほど $L_{c}$ は大きく推定された。

（3）千葉アレイ観測施設の隣接地点間における地震観測記録より、 $L_{c}$ および表層地盤の不均質パラメータ（相関距離、変動係数） を推定した。その結果、観測点間の離間距離と $L_{c}$ との関係は、 （2）の地震動シミュレーションによる評価結果とほぼ同様の 傾向を示すことを確認した。また相関距離は水平方向の方が 鉛直方向の相関距離よりも大きく推定される傾向が見られる ことを確認した。

今後は地震動の空間変動を評価するための周波数帯域をさらに明 確にし、 $L_{c}$ をより適切に推定できるようにすること、また観測記録 に含まれる斜め入射等が地震動の空間変動特性および地盤の不均質 パラメータの推定におよぼす影響について解明する必要がある。

\section{謝辞}

查読者の方から貴重なご助言をいただき、論文の改善に大変役立 ちました。震災予防協会（当時）より公開された千葉アレイ観測施 設の観測記録を使用いたしました。一部の作図に GMT を使用いた しました。ここに記して感謝申し上げます。

\section{参考文献}

1) Luco, J.E. and Wong, H.L.: Response of a Rigid Foundation to a Spatially Random Ground Motion, Earthquake Engineering and Structural Dynamics, Vol.14, pp.891-908, 1986

2) Sato, H. and Yamanaka, H.: A study on modeling of deep subsurface structure considering random velocity fluctuation for estimation of broadband site amplification factor - Fundamental investigation in Niigata plain, Japan -, Journal of Structural and Construction Engineering (Transactions of AIJ), No.648, pp.289-298, 2010.2 (in Japanese)

佐藤浩章, 山中浩明：広帯域サイト増幅特性評価のための深部地盤の不 均質性のモデル化に関寸る研究一新潟平野を対象とした基礎的検討一, 日本建築学会構造系論文集，第 648 号, pp.289-298, 2010.2

3) Kanda, K. and Motosaka, M.: The evaluation of effects of spatial variability of soil properties, surface topography and spatial coherency of incident wave on ground motion amplification - The case of Kushiro J.M.A site -, Journal of Structural and Construction Engineering (Transactions of AIJ), No.476, pp.85-94, 1995.10 (in Japanese)

神田克久, 源栄正人: 不均質・不整形性および入力コヒーレンスが地震 動特性に及ぼす影響評価一釧路地方気象台の場合一, 日本建築学会構 造系論文集，第 476 号, pp.85-94, 1995.10

4) Tokumitsu, R., Yamamoto Y. and Uchiyama Y.: Evaluation of magnitude, hypocenter distance and subsurface soil effect to spatial variability of ground motions between adjacent sites, Japan Association for Earthquake Engineering Papers, Vol. 19, No.1, pp.3452, 2019 (in Japanese)

徳光亮一, 山本優, 内山泰生：地震規模・震源距離および表層の地盤構 造が隣接地点間における地震動の空間変動に与える影響, 地震工学会 論文集，第 19 巻，第 1 号, pp.34-52, 2019

5) Tokumitsu, R., Yamamoto Y. and Uchiyama Y.: A study on effects of subsurface soil properties on the spatial variability of ground motions, Japan Association for Earthquake Engineering Papers, Vol. 19, No.5, pp.156-169, 2019 (in Japanese)

徳光亮一, 山本優, 内山泰生：表層の地盤物性が隣接地点間における地 震動の空間変動に与える影響に関寸る検討，地震工学会論文集，第 19 巻, 第 5 号, pp.156-169, 2019
6) Aki, K. and Chouet, B.: Origin of coda waves : source, attenuation and scattering effects : J. Geophys. Res., 80, pp.3322-3342, 1975

7) Shapiro, S.A. and Kneib, G.: Seismic attenuation by scattering: theory and numerical results, Geophys. J. Int., 114, pp.373-391, 1993

8) Ritter, J.R.R., Shapiro, S.A. and Schechinger, B.: Scattering parameters of the lithosphere below the Massif Central, France, from teleseismic wavefield records, Geophys. J. Int., 134, pp.187-198, 1998

9) Born, M. and Wolf, E. : Principal of optics $7^{\text {th }}$ (expanded) edition III, translated by Kusakawa, T., Tokai Univ. Press, 2006 (in Japanese) Born, M. and Wolf, E. : 光学の原理 第 7 版 III, 草川徹訳, 東海大学出 版会, 2006

10) Ishimaru, A.: Wave propagation and scattering in random media, Vols 1 and 2, Academic Press, New York, 1978

11) Shapiro, S.A., Schwarz, R. and Gold, N.: The effect of random isotropic inhomogeneities on the phase velocity of seismic waves, Geophys. J. Int., 127, pp.783-794, 1996

12) Kawahara, J.: Numerical simulations of seismic wave propagation in random media, Journal of the Seismological Society of Japan, Series 2, Vol.50, pp.135-156, 1997 (in Japanese)

河原純: ランダム媒質中の波動伝播の数值シミュレーション, 地震 第 2 輯, Vol.50, pp.135-156, 1997

13) Sato, H., Yamanaka, H., Higashi, S., Sato, K., Shiba, Y., Motoki, K., Mizuta, T.:Exploration of deep S-wave velocity structure in Niigata and Shonai plains to estimate long-period earthquake ground motion, Journal of the Seismological Society of Japan, Series 2, Vol.61, pp.191-205, 2009 (in Japanese)

佐藤浩章, 山中浩明, 東貞成, 佐藤清隆, 芝良昭, 元木健太郎, 水田敏 彦：長周期地震動評価のための新潟平野および庄内平野における深部 S 波速度構造の推定，地震 第 2 輯, Vol.61, pp.191-205, 2009

14) Hoirkawa, H., Yoshimi, M., Sekiguchi, H., Yoshida, K., Sugiyama, Y., Satake, K., Fukuwa, N., Suzuki H., Matsuyama, H., Liu Y., Takizawa, F.: A three-dimensional subsurface structure model of the Chukyo area, central Japan, Annual report on active fault and paleoearthquake researches, No.8, pp.203-254, 2008 (in Japanese) 堀川晴央, 吉見雅行, 関口春子, 吉田邦一, 杉山雄一, 佐竹健治, 福和 伸夫, 鈴木晴彦, 松山尚典, 劉瑛, 滝沢文教：中京地域の 3 次元地盤構 造モデル, 活断層・古地震研究報告, No.8, pp.203-254, 2008

15) Akita, S., En, K., Kudo, W., Morobishi, R. and Miyamoto, Y.: Study on modeling reduction in high-frequency component of input motion at heterogeneous hard-rock sites, Journal of Structural and Construction Engineering (Transactions of AIJ), No.694, pp.21132121, 2013.12 (in Japanese)

秋田昇道，圓幸史朗，工藤涉，諸菱亮太，宮本裕司：硬質な不均質地盤 における高周波入力動低減効果のモデル化に関する研究，日本建築学 会構造系論文集，第 694 号, pp.2113-2121, 2013.12

16) Frankel, A. and Clayton, R.W.: Finite difference simulations of seismic scattering: Implications for the propagation of short - period seismic waves in the crust and models of crustal heterogeneity, J. Geophs. Res., 91, pp.6455-6489, 1986

17) Roth, M. and Korn, M.: Single scattering theory versus numerical modelling in 2-D random media, Geophys. J. Int., Vol.112, pp.124140, 1993

18) Katayama, T., Yamazaki, F., Nagata, S. and Sato, N.: Earthquake observation by a three-dimensional sekismometer array and its strong motion database, Journal of JSCE, Vol.422, I -14, pp.361-369, 1990 (in Japanese)

片山恒雄, 山崎文雄, 永田茂, 佐藤暢彦: 高密度 3 次元アレーによる地 震動観測と記録のデータベース化，土木学会論文集，第 422 号，I - 14, pp.361-369, 1990

19) National Research Institute for Earth Science and Disaster Resilience: Japan Seismic Information Hazard Station J-SHIS, http://www.j-shis.bosai.go.jp/ (accessed 2021. 4.8) 防災科学技術研究所：地震ハザードステーション J-SHIS http://www.j-shis.bosai.go.jp/ (参照 2021.4.8) 


\author{
Ryoichi TOKUMITSU ${ }^{* 1}$, Yu YAMAMOTO ${ }^{* 2}$, Yasuo UCHIYAMA *2 \\ and Susumu $O H N{ }^{* 3}$ \\ *1 Taisei Advanced Center of Technology, Taisei Corporation, M.Eng. \\ *2 Taisei Advanced Center of Technology, Taisei Corporation, Dr.Eng. \\ * 3 Assoc. Prof., International Research Institute of Disaster Science, Tohoku Univ., Dr.Eng.
}

It has been pointed out that the spatial variation of ground motion between adjacent points has the effect of reducing the input ground motion to the building. In order to incorporate the effects of spatial variation of ground motion in the seismic design of buildings, it is necessary to consider the inhomogeneity of the subsurface soil in modeling the subsurface soil, as well as clarifying the depth of subsurface soil to be modeled. In this paper, the relational equation between the inhomogeneity of the subsurface soil and the spatial variation of the ground motion between adjacent points is constructed, and applies the equation to the response data extracted from the ground motion simulation using the three-dimensional heterogeneous soil model and the observation records between the adjacent points on the Chiba array observation system, to estimate parameters in heterogeneous subsurface soil and the depth of soil $L_{c}$ that governs the spatial variation of ground motion between adjacent points.

The relational equation between the inhomogeneity of the subsurface soil and the spatial variation of the ground motion between adjacent points $\varepsilon$ is based on the scattering theory and consists of the correlation distance of the $\mathrm{S}$ wave velocity $a$ and the fluctuation coefficient $\mu$, scattering angle $\psi$, as an index of the inhomogeneity of the subsurface soil, the propagation distance of the seismic motion, that is, $L_{c}$. With these parameters, the spatial variation of the observation records between adjacent points is expressed by an integral equation in frequency region.

In the seismic ground motion simulation using the three-dimensional heterogeneous soil model, multiple heterogeneous soil models with different correlation distances $a$ are constructed, the spatial variation of the seismic response between adjacent points $\varepsilon$ on the ground surface is calculated, and estimated the soil depth which affects the spatial variation of ground motion $L_{c}$ by applying the relational equation of $a, \mu, \psi$ and $\varepsilon$. As a result, it was estimated that the value of $L_{c}$ increases as the separation distance between adjacent points increases.

In the analysis of seismic observation records on the Chiba array, the spatial variation $\varepsilon$ of the $\mathrm{S}$ wave initial ground motion between adjacent points was calculated, and the relational equation with $a, \mu, \psi$ and $\varepsilon$ is applied to estimate $L_{c}$ for each separation distance, as well as the inhomogeneous parameters $(a, \mu)$ of the subsurface soil. As a result, $L_{c}$ increases as the separation distance between the observation points increases, which is the same trend as the seismic motion simulation using the three-dimensional heterogeneous soil model. Also, it is confirmed that the correlation distance $a$ of the surface ground $\mathrm{S}$ wave velocity tends to be larger in the horizontal direction than in the vertical direction. 